\title{
Historical record of mercury contamination in sediments from the Babeni Reservoir in the Olt River, Romania
}

\author{
Andrea Garcia Bravo • Jean-Luc Loizeau • \\ Lydie Ancey • Viorel Gheorghe Ungureanu • \\ Janusz Dominik
}

Received: 25 April 2008 / Accepted: 2 October 2008 /Published online: 21 October 2008

(C) Springer-Verlag 2008

\begin{abstract}
Background, aim and scope Mercury ( $\mathrm{Hg}$ ) is a ubiquitous and hazardous contaminant in the aquatic environment showing a strong biomagnification effect along the food chain. The most common transfer path of $\mathrm{Hg}$ to humans is contaminated fish consumption. In severely exposed humans, Hg poisoning may lead to damage in the central nervous system. Thus, it is important to examine current and past contamination levels of $\mathrm{Hg}$ in aquatic milieu. The Olt River is the largest Romanian tributary of the Danube River. The use of $\mathrm{Hg}$ as an electrode in a chlor-alkali plant contributed to the contamination of the aquatic environment in the $\mathrm{Rm}$ Valcea region. The purpose of this study was to compare the current state of $\mathrm{Hg}$ contamination with the past contamination using a historical record obtained from a dated sediment core from one of the Olt River reservoirs (Babeni) located downstream from the chlor-alkali plant. To our knowledge, no published data on $\mathrm{Hg}$ contamination in this region are available. The Babeni Reservoir was selected for this study because it is situated downstream from the chlor-alkali plant, whilst the other reservoirs only retain the pollutants coming from the upstream part of the watershed. Preliminary analyses (unpublished) showed high
\end{abstract}

ESPR Special issue-ESTROM

Responsible editor: Walter Giger

A. G. Bravo $(\bowtie) \cdot J .-L$. Loizeau $\cdot$ L. Ancey $\cdot$ J. Dominik

Institut F.-A. Forel, University of Geneva,

10 Route de Suisse,

1290 Versoix, Switzerland

e-mail: andrea.garcia@terre.unige.ch

V. G. Ungureanu

Faculty of Geology and Geophysics, University of Bucharest,

Bucharest, Romania
$\mathrm{Hg}$ concentrations in the surface sediment of the Babeni Reservoir. One core was taken in the upstream Valcea Reservoir to provide a local background level of $\mathrm{Hg}$ concentrations in sediments.

Results and discussion Sediment texture was uniform in the cores from both reservoirs. Laminated sediment structure, without any obvious discontinuities, was observed. $\mathrm{Hg}$ concentrations in the sediment core from the Valcea Reservoir were low and constant $(0.01-0.08 \mathrm{mg} / \mathrm{kg})$. In Babeni Reservoir sediments, $\mathrm{Hg}$ concentrations were very high in the deeper core section (up to $45 \mathrm{mg} / \mathrm{kg}$ in the longest core) and decreased to lower concentrations toward the top of the cores $(1.3-2.4 \mathrm{mg} / \mathrm{kg})$. This decrease probably reflects technological progress in control of emissions from the $\mathrm{Hg}$-cell-based chlor-alkali industry. Two strong peaks could be distinguished in older sediments. The mean rate of sedimentation $(5.9 \mathrm{~cm} /$ year $)$ was calculated from the depth of the ${ }^{137} \mathrm{Cs}$ Chernobyl peak. This was in good agreement with the sedimentation rate estimated at this site from a bathymetric study. Assuming a constant sedimentation rate, the two $\mathrm{Hg}$ peaks would reflect two contamination events in 1987 and 1991, respectively. However, it is also possible that the two peaks belong to the same contamination event in 1987 but were separated by a sediment layer richer in sand and silt. This layer had a low $\mathrm{Hg}$ concentration, which can be interpreted as a mass deposition event related to a major flood bringing $\mathrm{Hg}$-free sediments.

Conclusions Whilst the chlor-alkali plant partly switched to a cleaner technology in 1999, no obvious decrease of $\mathrm{Hg}$ concentrations was observed in recent decade. Results from the sediment core reflected the historical trend of $\mathrm{Hg}$ release from the chlor-alkali plant, revealed important contamination episodes and confirmed a legacy of contamination of $\mathrm{Hg}$ in recent sediments even if the concentrations of $\mathrm{Hg}$ 
decreased toward the surface due to a more efficient emission control.

Recommendations and perspectives Although the $\mathrm{Hg}$ concentrations in Babeni Reservoir sediments were extremely high in the late eighties and they remain one order of magnitude higher in the surface sediments than in sediments from the upstream reservoir, little is known about the transfer of $\mathrm{Hg}$ to the biota and human population. Our initial measurements indicate the presence of monomethyl$\mathrm{Hg}(\mathrm{MMHg})$ in pore water, but further studies are necessary to evaluate fluxes of $\mathrm{MMHg}$ at the sediment-water interface. Samples of fish and hair from various groups of the local population were recently collected to evaluate the potential hazard of $\mathrm{Hg}$ contamination to human health in the $\mathrm{Rm}$ Valcea region.

Keywords ESTROM $\cdot$ Historical record $\cdot \mathrm{Hg} \cdot$ Mercury . Olt River $\cdot$ Reservoir $\cdot$ Sediment

\section{Background, aim and scope}

Mercury is a ubiquitous and hazardous contaminant in the aquatic environment (Boening 2000). In severely exposed humans, Hg poisoning may lead to damage in the central nervous system (Clarkson 1997). This trace element is considered to be a global pollutant (UNEP 2002) because once in the atmosphere, it is widely disseminated and can circulate for years before its deposition. Relatively high $\mathrm{Hg}$ concentrations were found in remote areas with no proximate sources of pollution, such as the Artic region (Hylander and Goodsite 2006). Since the industrial revolution, anthropogenic Hg fluxes have increased compared to the pre-industrial levels (Lamborg et al. 2002). Hg can enter aquatic systems via several pathways: dry and wet atmospheric deposition, surface runoff and/or directly from locally polluted wastewater. The toxicity of $\mathrm{Hg}$ in the aquatic environment depends on its chemical forms (Clarkson 1997). Monomethyl-Hg (MMHg) is the main form of $\mathrm{Hg}$ that bioaccumulates and biomagnifies in fish, and the elimination of $\mathrm{MMHg}$ from fish requires a relatively long time. Consumption of $\mathrm{Hg}$ contaminated fish is the most common exposure pathway for humans.

Lake and reservoir sediments store contamination information for particle-bound pollutants. Sediments can be a sink and/or a secondary source for many types of pollutants (Förstner and Wittmann 1979; Förstner 2004; Linnik and Zubenko 2000) including $\mathrm{Hg}$ (Ullrich et al. 2001). Historical reconstructions of $\mathrm{Hg}$ pollution from sedimentary record have been obtained in lakes (e.g. Dominik et al. 1991, 1992; Loizeau et al. 2004) and reservoirs (Arnason and Fletcher 2003; Gray et al. 2005; Castelle et al. 2007). Reservoirs are often located close to industrial centres, thus close to the sources of pollution. The elevated rate of sedimentation in reservoirs (generally higher than in natural lakes) attenuates early diagenesis and decreases the bioturbation activity; hence, post-depositional alterations are less important and seasonal lamination can be better preserved. The local point sources of pollution can be particularly well evaluated if another reservoir retains particle-bound pollutants originating from the upstream portion of the watershed.

The Olt River, which is $615 \mathrm{~km}$ long and has a catchment area of $24,050 \mathrm{~km}^{2}$, is the largest Romanian tributary of the Danube River. In the middle and lower reaches of the Olt River, 19 dams and reservoirs have been constructed in the last 30 years for flood control and power generation. These reservoirs are important sources of fish for the local population. Therefore, $\mathrm{Hg}$ pollution may pose a risk to human and wildlife populations that consume large amounts of fish.

The $\mathrm{Rm}$ Valcea region was selected for this study because it contains a high concentration of industrial companies including a large chlor-alkali plant. Among $\mathrm{Hg}$ point sources, chlor-alkali plant effluents were particularly important for $\mathrm{Hg}$ releases (USEPA 1997). This is especially true in Europe (UNEP 2002) before Hg-free technologies had been adopted. Some $43 \%$ of total capacity of European production in 2006 used mercury-cell technology (Eurochlor 2007). However, the effects of pollution can be observed long after the plants have stopped using $\mathrm{Hg}$ technology (USEPA 1997). The use of $\mathrm{Hg}$ as an electrode in the Oltchim chlor-alkali plant contributed to the contamination of the aquatic environment in the Valcea region. Other $\mathrm{Hg}$ sources were not identified in the region. According to the document of the Romanian Ministry of Environment and Water Management (MEWM 2006), two units with $\mathrm{Hg}$ cells were put into operation in 1968 and 1974 with production capacities of 100,000 and 210,000 tons/year $\mathrm{NaOH}$, respectively. The former was closed in 1999, whilst the latter is still operating. Another unit of 100,000 capacity, based on mercury-free diaphragm electrolysis, was in use between 1984 and 1993. Finally, a unit of 120,000 capacity, based on membrane technology, was activated in 2000 .

There is no available data about the historical and current $\mathrm{Hg}$ releases from the Oltchim chlor-alkali plant, and little is known about the degree of $\mathrm{Hg}$ pollution in the region. Therefore, this study aimed to compare the current state of $\mathrm{Hg}$ contamination in sediments with the past contaminations using a historical record obtained from dated sediment cores from one of the Olt River reservoirs (Babeni) located downstream of the chlor-alkali plant. This research provided evidence that Babeni Reservoir is still Hg-contaminated, but with a much smaller degree than in the late 1980s. In addition, contamination by other metals 
Fig. 1 Coring site locations in Babeni (OLTBC5, OLTBC12, OLTBC13) and Valcea (OLTVC5) reservoirs. The chlor-alkali plant discharging wastewater into the Olt River just upstream from Babeni Reservoir (bold arrow) is located at the industrial platform

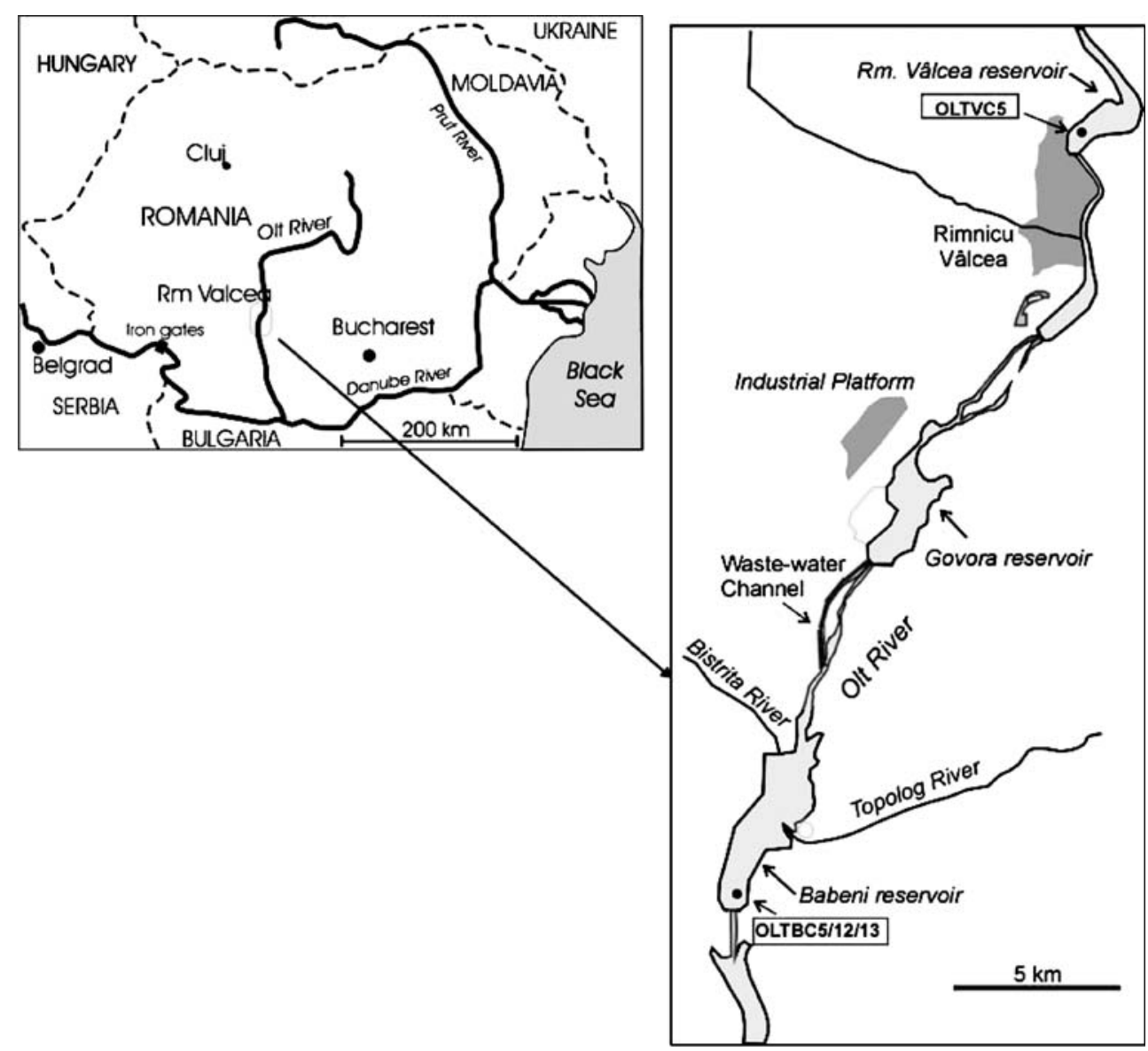

was also examined in sediments to verify the impact of other local industries and domestic wastewaters.

\section{Materials and methods}

\subsection{Setting and sampling locations}

The Babeni Reservoir (Fig. 1) has a surface area of 905 ha, a mean volume of 35.3 millions per cubic metre and a mean depth of $3.9 \mathrm{~m}$. It was built in 1976 downstream from a chlor-alkali discharge channel. The mean yearly flows of the Olt River during the period 1995-2004 were in the ranges of $101-191$ and $103-194 \mathrm{~m}^{3} / \mathrm{s}$ at the entrance and the exit of the reservoir, respectively. The river flow is regulated by hydroelectric plants. Two rivers flow into Babeni Reservoir, the Bistrita (mean yearly discharge 1.3$5.7 \mathrm{~m}^{3} / \mathrm{s}$ ) and the Topolog (mean yearly discharge 1.0 $4.6 \mathrm{~m}^{3} / \mathrm{s}$ ). The two rivers have a torrential character with a peak monthly flow reaching 20.1 and $11.6 \mathrm{~m}^{3} / \mathrm{s}$, respectively (period 1985-2004).

Two sediment cores (OLTBC5 and OLTBC12; Table 1) were collected in August 2006 from the Babeni Reservoir, close to the dam, at a water depth of $17 \mathrm{~m}$ where fine sediments were expected to deposit without any influence of the stream current. These cores were recovered at about $200 \mathrm{~m}$ from each other. An additional core (OLTBC13) was taken in October 2007 from the same area, approximately $70 \mathrm{~m}$ from the OLCBC12 location. One core (OLTVC5; see Table 1) was taken from the Valcea Reservoir in 2006, located upstream from the industrial platform, to provide a local background level of heavy metal concentrations in sediments. All cores were recovered using a $60-\mathrm{mm}$ gravity corer (UWITEC, Austria).

Table 1 Sampling location and length of the three sediment cores

\begin{tabular}{lllc}
\hline Sample & Sampling date & Sampling site & $\begin{array}{l}\text { Core } \\
\text { length }(\mathrm{cm})\end{array}$ \\
\hline OLTBC5 2006 & Aug 2006 & $\begin{array}{l}44^{\circ} 55^{\prime} 20.9 \\
24^{\circ} 14^{\prime} 49.2\end{array}$ & 76 \\
& & $44^{\circ} 55^{\prime} 20.8$ & 126 \\
OLTBC12 2006 & Aug 2006 & $24^{\circ} 14^{\prime} 52.5$ & \\
& & $45^{\circ} 57^{\prime} 33.303$ & 76 \\
OLTVC5 2006 & Aug 2006 & $24^{\circ} 22^{\prime} 40.954$ & \\
& & $44^{\circ} 55^{\prime} 14.6$ & 56 \\
OLTBC13 2007 & Oct 2007 & $24^{\circ} 14^{\prime} 55.2$ & \\
\hline
\end{tabular}

Sampling locations are reported in Fig. 1 


\subsection{Laboratory analyses}

All cores were kept vertically at $4^{\circ} \mathrm{C}$ until a volume magnetic susceptibility (VMS) profile with 0.5 -cm intervals was obtained using a MS2 susceptibility metre (Bartington Instruments, Oxford, England). With the exception of OLTBC13, all the cores were cut longitudinally within $6 \mathrm{~h}$ of collection and were sediment-photographed and described for colour, laminations and particular features. For a technical reason, core OLTBC13 was opened 8 days after collection once transferred to the laboratory in Geneva.

The sediment cores were subsampled with a constant interval of $1 \mathrm{~cm}$ except for sediment layers showing particular features (colour, texture). Samples were homogenised and split for various analyses in the Geneva laboratory: (1) radionuclide gamma counting; (2) metals (except $\mathrm{Hg}$ ), (3) $\mathrm{Hg}$ (total particulate $\mathrm{Hg}$ ), (4) loss on ignition (LOI) and (5) water content. Subsamples were weighted, air-dried to a constant weight and weighed again to obtain water content and porosity following the procedure of Sugai et al. (1994). Dry samples were powdered and homogenised with an agate mortar and stored in the dark until analysis. Metals were extracted from dry sediments using the 'OSol' procedure (O-sol 1998) consisting of digestion with $2 \mathrm{~N} \mathrm{HNO}_{3}$ at $100^{\circ} \mathrm{C}$ overnight. Trace element concentrations (except for $\mathrm{Hg}$ ) were measured using inductively coupled plasma mass spectrometry (ICP-MS, Agilent, HP 4500) through the use of external calibration and an internal standard (Canadian Certified Reference Materials Project, Ottawa, Ontario, Canada). Two reference materials (LKSD-1 and LKSD-3) and blanks were run frequently to verify the accuracy and to determine detection limits. All metals but $\mathrm{Zn}$ measurements were within the certified range. The $\mathrm{Zn}$ variation compared to certified value in LKSD-3 reaches $11 \%$. The precision of measurements from replicate analyses was better than $10 \%$. The Total Hg in sediment samples was determined using an atomic absorption spectrophotometer for $\mathrm{Hg}$ determination (Advanced Hg Analyser; AMA 254, Altec s.r.l., Czech Republic). The accuracy of measurements was frequently checked by analysing lake sediment reference material WQB-3 (National Water Research Institute, Canada). The measured values were in the certified ranged for all analyses. Precision determined by replicate analysis was better than $4 \%$.

The LOI, a surrogate of organic matter content (Dean 1974), was measured by heating sediments at $550^{\circ} \mathrm{C}$ for $1 \mathrm{~h}$. Particle size analyses were performed with a LS-100 analyser (Beckman Coulter, Fullerton, CA, USA) followed by a 5 -min ultrasonic dispersal in deionised water (Loizeau et al. 1994).

${ }^{7} \mathrm{Be}$ and ${ }^{137} \mathrm{Cs}$ were directly measured on dried and pulverised sediment samples in a fixed-geometry vessel by gamma spectroscopy using a well detector (Dominik et al. 1987). ${ }^{7} \mathrm{Be}$ is produced in the atmosphere and attaches rapidly to particulate material. In most sedimentary systems without bioturbation activity, the radioisotope accumulates only in the surface (from 1 to $2 \mathrm{~cm}$ ) because the half-life ( $\approx 53$ days) is too short for ${ }^{7} \mathrm{Be}$ to accumulate in deeper sediment levels. The presence of ${ }^{7} \mathrm{Be}$ in the uppermost section of a core is a good indicator for the most recently deposited sediment (Dominik et al. 1992). For sediments younger than 40 years, ${ }^{137} \mathrm{Cs}$ is a useful time marker (Albrecht et al. 1998) from which one can derive the pollution chronology. This method is especially valuable in sediments accumulating at a high rate where ${ }^{210} \mathrm{~Pb}$ dating is difficult or impossible.

Statistical analyses ( $t$ tests) were performed using SPSS (15.0) software.

\section{Results}

OLTBC5, OLTBC12 and OLTBC13 presented similar VMS (not shown) and Hg profiles (Fig. 2). These three cores were sampled in the polluted reservoir. OLTBC12 was selected for a detailed study because it was the longest and the ${ }^{137} \mathrm{Cs}$ peak attributed to the Chernobyl reactor accident (1986) was observed at a depth of $118 \mathrm{~cm}$. The similitude of $\mathrm{Hg}$ profiles, both in shape and amplitude, showed that these cores are representative of the sedimentary record of the lower part of the reservoir.

The sediment structure and texture were uniform in OLTVC5 in the core from Valcea reservoir (OLTVC5, not

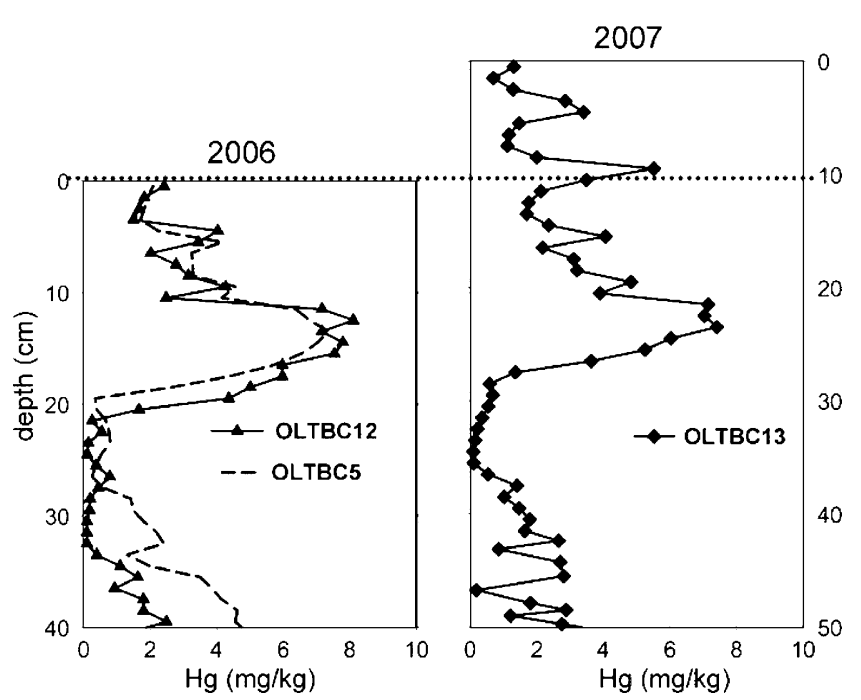

Fig. 2 Mercury concentration profiles in sediments from cores recovered in 2006 (OLTBC5, OLTBC12) and 2007 (OLTBC13). The complete $\mathrm{Hg}$ concentration profile from the longest core (OLTBC12) is shown in Fig. 3 
Fig. 3 Grain size (percentage of clay, silt, and sand fractions), $\mathrm{Hg}$ concentration and ${ }^{137} \mathrm{Cs}$ activity in sediments from core OLTBC12

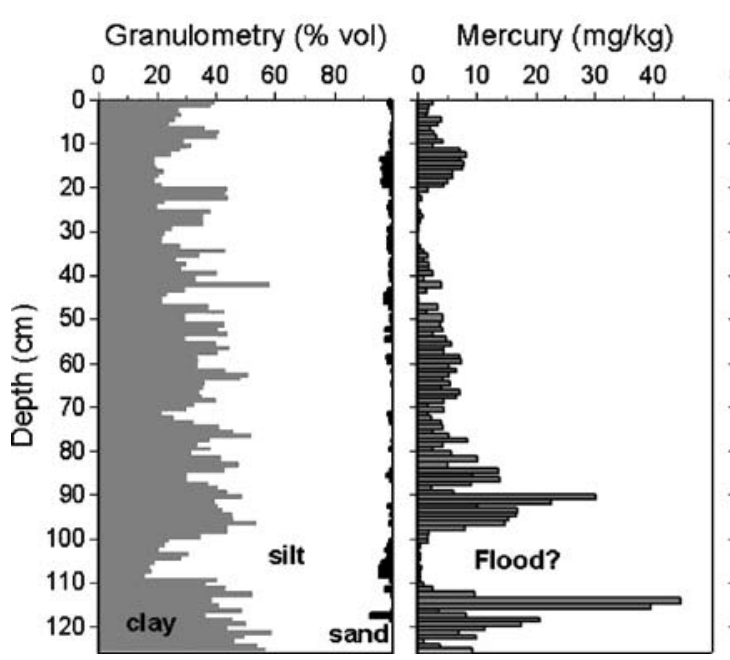

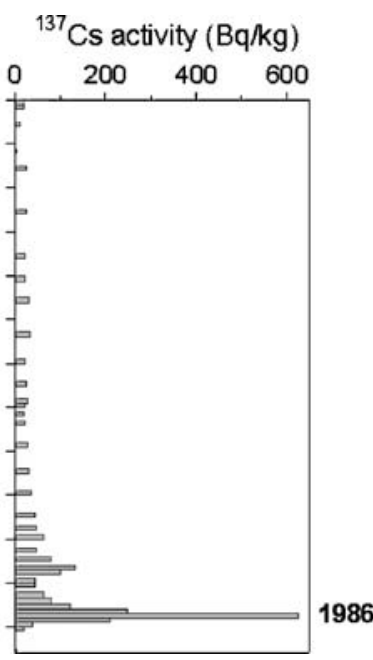

shown). Sediments were composed of well-sorted silt $(>80 \%)$. In the OLTBC12 core, the sediment structure showed some lamination without any evident relation to seasons and with little obvious evidence of discontinuities or bioturbation, but was more variable than core OLTVC5. Core OLTBC12 sediments consisted of an alternation of silts, clayey silts and silty clays with a minor amount of sand (maximum 7\%), particularly between 12-18 and 100$109 \mathrm{~cm}$ depths (Fig. 3). The mean clay percentage decreased toward the surface. It was significantly higher $(38 \%)$ in older sediments $(96-126 \mathrm{~cm})$ than in the first $30 \mathrm{~cm}(29 \% ; p<0.001)$. The opposite behaviour was found for the silt fraction, which increased toward the surface.

LOI varied from $6 \%$ to $14 \%$ (mean, $9 \pm 2 \%$ ) in the OLTBC12 core. No correlation with Hg concentrations was found along the whole length of the core $\left(R^{2}=0.006, p=\right.$ $0.587)$, even though the highest LOI and $\mathrm{Hg}$ concentration were found at the same depth $(111-112 \mathrm{~cm})$. Core OLTVC5 had a similar LOI (mean, $9 \pm 2 \%$; range, $6.5-15 \%$ ) to that of OLTBC12.

Heavy metal concentrations $(\mathrm{Cd}, \mathrm{Cu}, \mathrm{Pb}, \mathrm{Zn})$ were significantly higher in Babeni than in Valcea reservoir. Table 2 shows the values of mean, SD and $p$ values of $t$ test. $\mathrm{Hg}$ concentrations in sediment core from Valcea reservoir (OLTVC5) were low and fairly constant at $0.093 \pm$ $0.008 \mathrm{mg} / \mathrm{kg} \quad($ mean $\pm \mathrm{SD}, n=62)$. In Babeni sediments (OLTBC12), Hg concentrations were very high in the deeper core section and decreased to lower concentrations toward the top of the core $(2.40 \pm 0.01 \mathrm{mg} / \mathrm{kg}$; see Fig. 2). The two strong concentration peaks, $30.3 \pm 0.5$ and $45 \pm$ $1 \mathrm{mg} / \mathrm{kg}$ (see Fig. 3), could be distinguished in deeper sediments at 88-89 and 111-112 cm depths, respectively. The lowest two concentrations (less than $0.5 \mathrm{mg} / \mathrm{kg}$ ) were recorded in the core sections at 21-34 and 100-109 cm. In the upper section, a broad peak appeared between 11 and $20 \mathrm{~cm}$ depth, and two minor peaks occurred at 9-10 and 4-

Table 2 Mean concentration of selected heavy metal in Valcea and Babeni Reservoir sediments, and sediment guidelines for freshwater ecosystems (MacDonald et al. 2000)

\begin{tabular}{|c|c|c|c|c|c|c|c|c|c|c|c|}
\hline \multirow{3}{*}{ Core } & \multicolumn{11}{|c|}{ Metal (mg/kg) } \\
\hline & \multicolumn{2}{|l|}{$\mathrm{Cd}$} & \multicolumn{2}{|l|}{$\mathrm{Cu}$} & \multicolumn{2}{|l|}{$\mathrm{Pb}$} & \multicolumn{2}{|l|}{$\mathrm{Zn}$} & \multicolumn{2}{|l|}{$\mathrm{Hg}$} & \multirow[t]{2}{*}{ Notes } \\
\hline & Mean & SD & Mean & SD & Mean & $\mathrm{SD}$ & Mean & $\mathrm{SD}$ & Mean & SD & \\
\hline OLTVC5 & 0.5 & 0.24 & 46 & 5 & 23 & 3 & 127 & 16 & 0.09 & 0.01 & Background \\
\hline OLTBC12 & 1.37 & 1.19 & 59 & 16 & 37 & 17 & 176 & 65 & 5 & 71 & Polluted \\
\hline$p$ values $^{\mathrm{a}}$ & 0.03 & & 0.02 & & $<0.01$ & & 0.014 & & $<0.01$ & & \\
\hline Recommended values & & & & & & & & & & & \\
\hline SQGS-PEC ${ }^{\mathrm{b}}$ & 5 & & 149 & & 128 & & 459 & & 1.06 & & \\
\hline
\end{tabular}

$p$ values correspond to the probability that the means are equivalent ( $t$ test). All metal concentrations are significantly higher in OLTBC12 than in OLTVC5 $(p<0.05)$

${ }^{\mathrm{a}}$ Comparison of means with $t$ test

${ }^{\mathrm{b}}$ SQGS-PEC sediment quality guidelines (SQGs) for freshwater ecosystems, probable effect concentration. Concentrations below which harmful effects on life are unlikely to be observed (from MacDonald et al. 2000) 
$5 \mathrm{~cm}$. Visual correlation could be established between OLTBC12 and OLTBC13 based on sedimentary features. Cores presented similar lamination and other characteristics (e.g. colour, grain size, texture). The $\mathrm{Hg}$ concentration profiles in the upper section of OLTBC12 and in OLTBC13 were matched assuming that $10-\mathrm{cm}$ sediments were deposited during the time elapsed between the sampling dates (13.5 months), as shown in Fig. 2. This comparison further showed that the $\mathrm{Hg}$ concentrations in sediments deposited between August 2006 and October 2007 was still high (up to $5.5 \mathrm{mg} / \mathrm{kg}$ ).

The presence of ${ }^{7} \mathrm{Be}$ activity in the first centimetre in OLTBC12 $(203 \pm 18 \mathrm{~Bq} / \mathrm{kg})$ and OLTBC13 $(62 \pm 9 \mathrm{~Bq} / \mathrm{kg})$ confirmed a successful sampling of recent sediments. A strong ${ }^{137} \mathrm{Cs}$ peak $(625 \pm 17 \mathrm{~Bq} / \mathrm{kg})$ was observed at $117-118$ $\mathrm{cm}$ depth in OLTBC12 (see Fig. 3) and can be attributed to the Chernobyl accident. This depth corresponds to a cumulated dry sediment weight (cdsw) of $65 \mathrm{~g} / \mathrm{cm}^{2}$. A second minor peak, $131 \mathrm{~Bq} / \mathrm{kg}$, appeared at a depth of 106$107 \mathrm{~cm}$. A mean sediment accumulation rate (SAR) was estimated by dividing the cdsw at depth $117.5 \mathrm{~cm}$ by the time which had elapsed between April 1986 and August 2006. A mean SAR was $3.29 \mathrm{~g} \cdot \mathrm{cm}^{-2} \cdot$ year $^{-1}$, and the corresponding mean sedimentation rate expressed in a depth scale was $5.9 \mathrm{~cm} /$ year. As the water content varied little with depth, the timescale (age) can be applied directly to the depth scale.

Based on visual correlation and $\mathrm{Hg}$ concentrations in OLTBC12 and OLTBC13 (see Fig. 2), we concluded that $10 \mathrm{~cm}$ of sediments were deposited from August 2006 until October 2007. The calculated sedimentation rate for this year was approximately $8.9 \mathrm{~cm} /$ year with an estimated SAR of $6.70 \mathrm{~g} \cdot \mathrm{cm}^{-2} \cdot \mathrm{year}^{-1}$.

\section{Discussion}

4.1 $\mathrm{Hg}$ pollution evidence and comparisons with other polluted sites

Industrial discharges are the main source of pollution into the Olt River upstream from the Babeni Reservoir. To evaluate the impact of these discharges on the sediment contamination, we have examined the concentrations of $\mathrm{Hg}$ and other metals such as $\mathrm{Cd}, \mathrm{Cu}, \mathrm{Pb}$ and $\mathrm{Zn}$ in the Babeni Reservoir sediments. The concentrations were compared to those obtained from the Valcea Reservoir (see Table 2), which is located upstream from the industrial platform. In addition, we compared the pollution level in the Babeni sediments with sites recently polluted by $\mathrm{Hg}$ throughout the world (Table 3) and some other water systems polluted by chlor-alkali plants (Table 4).

Significantly higher metal concentrations ( $t$ test) were observed in sediments from Babeni Reservoir than in sediments from Valcea Reservoir (see Table 2). Except for $\mathrm{Hg}$, mean heavy metal concentrations in Babeni Reservoir sediments were lower than the consensus-based sediment quality guidelines-probable effects concentrations (SQGPEC) values proposed by MacDonald et al. (2000). Moreover, $\mathrm{Cd}, \mathrm{Cu}, \mathrm{Pb}$ and $\mathrm{Zn}$ concentrations in surface sediments from core OLTBC12 (see Table 3) were similar to their mean concentrations at the reference site (OLTVC5), indicating that pollution by these metals originated from the industrial platform is not an issue any more. In contrast, the mean content of $\mathrm{Hg}$ in Babeni sediments was five times higher than SQGs-PEC values. The highest Hg concentration in the 111-112 cm layer was

Table 3 Comparison of heavy metal concentrations in Babeni Reservoir sediments with published results from similar settings

\begin{tabular}{|c|c|c|c|c|c|c|c|}
\hline \multirow[b]{2}{*}{ Location } & \multicolumn{7}{|c|}{ Trace element concentration $(\mathrm{mg} / \mathrm{kg})$} \\
\hline & & $\mathrm{Cd}$ & $\mathrm{Cu}$ & $\mathrm{Pb}$ & $\mathrm{Zn}$ & $\mathrm{Hg}$ & Reference \\
\hline \multirow[t]{3}{*}{ Babeni Reservoir ${ }^{\mathrm{a}}$ Olt River Roumania } & Mean & 1.4 & 59 & 38 & 176 & 5 & \multirow[t]{3}{*}{ This study } \\
\hline & Max & 4.8 & 117 & 94 & 371 & 44 & \\
\hline & Surface & 0.52 & 47 & 25 & 123 & 2.4 & \\
\hline \multirow[t]{3}{*}{ Patroon ReservoirUnited States } & Mean & - & - & - & - & - & \multirow[t]{3}{*}{ Arnason and Fletcher 2003} \\
\hline & Max & 25 & - & 3,600 & - & 6 & \\
\hline & Surface & 1 & - & 100 & - & $<1$ & \\
\hline \multirow[t]{3}{*}{ Lake Geneva Switzerland } & Mean & 12 & 378 & 393 & 2,762 & l & \multirow[t]{3}{*}{ Loizeau et al. 2004} \\
\hline & Max & 27.2 & 1,583 & 939 & 5,817 & 5.6 & \\
\hline & Ref value & 0.2 & 30 & 30 & 60 & 0.03 & \\
\hline \multirow[t]{3}{*}{ Cajarc reservoir Lot River France } & Mean & 125 & 98 & 523 & 4430 & 1 & \multirow{3}{*}{$\begin{array}{l}\text { Audry et al. } 2004 \\
\text { Castelle et al. } 2007\end{array}$} \\
\hline & $\operatorname{Max}$ & 294 & 264 & 1,280 & 10,000 & $35^{\mathrm{c}}$ & \\
\hline & Ref value $^{\mathrm{b}}$ & 0.81 & 27 & 436 & 134 & $0.05^{\mathrm{b}, \mathrm{c}}$ & \\
\hline Recommended values & See Table 2 & & & & & & \\
\hline
\end{tabular}

${ }^{\mathrm{a}}$ Data from OLTBC12 core

${ }^{\mathrm{b}}$ Reference values: Marcenat reservooir, Audry et al. (2004)

${ }^{\mathrm{c}} \mathrm{Hg}$ concentration in Cajarc and Marcenat reservoir, Castelle et al. (2007) 
Table 4 Polluted lakes and reservoirs by chlor-alkali plant and similar activities

\begin{tabular}{|c|c|c|c|c|c|c|c|c|c|c|c|c|c|c|}
\hline \multirow[t]{2}{*}{ Site } & \multicolumn{3}{|c|}{ Babeni Reservoir } & \multicolumn{3}{|c|}{ Lake Balkydak } & \multicolumn{3}{|c|}{ Lake Vänern } & \multicolumn{3}{|c|}{ Fukuro Bay } & \multicolumn{2}{|c|}{ Swedish Estuaries } \\
\hline & Mean & Max & Surf & Mean & Max & Surf & Mean & Max & Surf & Mean & Max & Surf & Köpmanholmen & Skutskär \\
\hline $\begin{array}{l}\mathrm{Hg} \\
\text { concentrations } \\
(\mathrm{mg} / \mathrm{kg})\end{array}$ & 5.5 & 44 & 2.5 & 76 & 617 & 151 & - & $<12^{\mathrm{b}}$ & $0.5^{\mathrm{b}}$ & $2.9^{\mathrm{a}}$ & $9^{\mathrm{a}}$ & $4.8^{\mathrm{a}}$ & $250^{\mathrm{c}}$ & $150^{\mathrm{c}}$ \\
\hline Reference & \multicolumn{3}{|c|}{ This study } & \multicolumn{3}{|c|}{ Ullrich et al. 2007} & \multicolumn{3}{|c|}{$\begin{array}{l}\text { Wihlborg and } \\
\text { Danielsson } 2006\end{array}$} & \multicolumn{3}{|c|}{ Tomiyasu et al. 2006} & \multicolumn{2}{|c|}{ Skyllberg et al. 2007} \\
\hline
\end{tabular}

\footnotetext{
${ }^{\text {a }}$ Fukuro Bay core number13 (average and surface values from the most contaminated core in the area)

${ }^{\mathrm{b}}$ Most contaminated site of the western part of Kattfjorden bay

${ }^{\mathrm{c}}$ Maximun concentrations found in surface sediments
}

42 times higher than SQGs-PEC values, and the concentrations exceeded the SQGs-PEC limit even in the most recent sediments

Table 3 shows the comparison between Babeni Reservoir and a few selected metal-polluted reservoirs or lakes in the world. Patroon Reservoir (USA), the Bay of Vidy in Lake Geneva (Switzerland) and Cajarc Reservoir (France) have been chosen for this comparison because they are located close to industrial areas and these studies have been performed recently; thus, the concentrations reflect the present pollution in freshwater sediments. This comparison confirms that the concentrations of metals other than $\mathrm{Hg}$ are relatively low in Babeni Reservoir. However, the maximum value of $\mathrm{Hg}$ in sediments of this reservoir is seven times higher than in the Patroon reservoir, almost eighr times higher than in the Bay of Vidy (Lake Geneva) and similar to the Cajarc reservoir.

Table 4 shows the comparison of $\mathrm{Hg}$ concentration between Babeni Reservoir and some other sites polluted by chlor-alkali plants: Fukuro Bay (Japan), Köpmanholmen and Skutskär estuaries (Sweden), Lake Vänern (Sweden) and Lake Balkydak (Kazakhstan). Fukuro Bay is a semiclosed, undredged ocean bay close to Minamata Bay. The maximal concentration in Babeni Reservoir exceeded the highest value in the most contaminated core from Fukuro Bay by a factor of five. However, the concentration in the surface sediments from Babeni Reservoir is almost half as high as in Fukuro Bay. Köpmanholmen and Skutskär are two Hg-polluted estuaries of the Bothnian Sea, Sweden (Skyllberg et al. 2007). The contaminated sediments from these estuaries reached concentrations ten times higher than Babeni Reservoir. The western part of Kattfjorden bay, in Lake Vänern, showed concentrations five and four times lower than those found in the surface sediments and in the historic maximum of Babeni Reservoir, respectively. Among all the aquatic systems compared in Table 4, Lake Balkydak sediment has the highest $\mathrm{Hg}$ level. Although $\mathrm{Hg}$ accumulates in sediments worldwide, the concentrations in sediments that are not directly contaminated by local sources are much lower. For example, a survey of nearly 600 sites in northeast North America showed a mean concentration in lake, reservoir and river sediments of $0.19 \mathrm{mg} / \mathrm{kg}$ (Kamman et al. 2005). In this context, the mean concentration of $0.09 \mathrm{mg} / \mathrm{kg}$ in sediments from the reference core OLTCV5 appears as a site free from local $\mathrm{Hg}$ contamination.

\subsection{Remnant pollution}

$\mathrm{Hg}$ concentrations in recent sediments from Babeni Reservoir (OLTBC12 and OLTBC13) are still at least one order of magnitude higher than the local background concentration. In this respect, several hypotheses on the origin of the recent pollution should be considered: (a) persistent high release of $\mathrm{Hg}$ from the production line of chlor-alkali plant or from the channels evacuating wastewater, (b) remobilization of old sediments and their redeposition and/or (c) $\mathrm{Hg}$ inputs coming from a diffuse contamination of the whole watershed. As one line of the Oltchim factory still uses $\mathrm{Hg}$ cell technology, hypothesis (a) is highly probable even if an effort to limit $\mathrm{Hg}$ emissions were undertaken. Regardless of the origin, the remnant $\mathrm{Hg}$ contamination of sediments may have a non-negligible impact on the ecosystem and human health.

4.3 Sedimentation rate and $\mathrm{Hg}$ historical pollution record: interpretations

The choice of the sampling point was crucial for a successful reconstruction of the contamination history from sediments and the calculation of the sedimentation rate. The sampling point location in the Babeni Reservoir was chosen considering the expected sedimentation rate inferred from a recent sediment thickness map (Ungureanu 2007), which reflects sediment dynamics in the reservoir. The calculated mean sedimentation rate $(5.9 \mathrm{~cm} /$ year $)$ derived from the depth of ${ }^{137}$ Cs Chernobyl peak is in good agreement with sedimentations from the sediment thickness map of the 
lower region of the reservoir (range, $6.7-13.3 \mathrm{~cm} /$ year). However, sedimentation rate between August 2006 and October 2007 was higher than the average sedimentation rate by a factor of 1.5 . This is qualitatively confirmed by a lower concentration of ${ }^{7} \mathrm{Be}$ in the uppermost samples in core OLTB13 than in core OLTBC12 because of the dilution of atmospheric ${ }^{7} \mathrm{Be}$ with a higher sediment flux in OLTBC13. Clearly, such fluctuation of the sedimentation rates occurred in the past and the dates attributed to the depth may locally demonstrate a substantial inaccuracy. The fluctuations of sedimentation rate are attributed to fluctuations of discharges from the Topolog and Bistrita streams, which flow directly into Babeni Reservoir, rather than to changes in the Olt River discharges, which are artificially regulated. Moreover, the Olt River carries less suspended load to the Babeni Reservoir, as a large portion of coarser suspended particles are trapped in the upstream reservoirs. In contrast, local floods can increase the sediment delivery from the Topolog and Bistrita streams as well as from other smaller creeks. Assuming a constant sedimentation rate of $5.9 \mathrm{~cm} /$ year, the two $\mathrm{Hg}$ peaks at 88 89 and 111-112 cm depths would reflect two contamination events in 1987 and 1991 from the chlor-alkali plant. However, it is also possible that the two peaks belong to the same contamination event in 1987, as the peaks were separated by a sediment layer richer in sand and silt, thus having very low $\mathrm{Hg}$ concentration, which could be interpreted as mass deposition events related to major floods. Moreover, ${ }^{137} \mathrm{Cs}$ content presented variations in these coarser sediments, including a local maximum, and was probably derived from the topsoil erosion during floods. Such variations indicate that this coarse deposit is heterogeneous and could result from the accumulation of a succession of sediment deposits. These interpretations imply that a series of flood events delivered coarser and poor-Hg sediments to the Babeni Reservoir. The data of monthly water flow records of the two creeks (Topolog and Bistrita) do not show any spectacular increase in 1986 and 1987, but the occurrence of short-term events cannot be excluded.

Even if it cannot be demonstrated for the whole core, it seems that relatively low $\mathrm{Hg}$ concentrations occur in the coarser sediments in the deeper core sections (OLTBC12) and higher $\mathrm{Hg}$ concentrations are seen in the finer organicmatter-rich sediments. This is certainly not true for the upper core section where coarser-grained sediments between 12 and $18 \mathrm{~cm}$ depth are clearly enriched in comparison to fine sediments. This can be interpreted as evidence that the current direct emissions from the factory decreased, but coarse material derived from the local surface runoff during floods delivered $\mathrm{Hg}$ from the contaminated watershed or industrial channels near the chlor-alkali factory.
Vink and Behrendt (2001) investigated the impacts of floods on sediment quality of river systems. Typically, two situations can be considered. If a watershed is not polluted, materials carried and ultimately deposited by floods have a lower concentration of pollutant than slowly accumulated sediments (dilution effect). In contrast, if the watershed is polluted and the point source has decreased or stopped its emissions, a flood event leads to a deposition of sediments with a higher concentration of pollutants. It seems that two such situations occurred successively in the Babeni Reservoir in the late 1980s and also recently (2007).

The chlor-alkali plant did not provide information about its $\mathrm{Hg}$ releases; thus, the historic and recent releases of $\mathrm{Hg}$ could not be related to the $\mathrm{Hg}$ profile in the Babeni core. However, a coherent combined record of historical $\mathrm{Hg}$ pollution from three cores in Babeni Reservoir shows a generally decreasing trend from a maximum in 1987 to the present. This decrease probably reflects the technological progress in control of emissions from the Hg-cell-based chlor-alkali industry. Eurochlor (2007) reported a spectacular decrease of mean $\mathrm{Hg}$ emissions from 8.1 to $1.4 \mathrm{~g} \mathrm{Hg} /$ ton of chlorine production capacity between 1985 and 1997 due to the technical advancements made in European factories. This means about a $83 \%$ reduction in 12 years. A decrease of a similar magnitude can be observed in $\mathrm{Hg}$ concentrations between the late 1980s (core section 110 $120 \mathrm{~cm}$ ) and late 1990s (core section 40-50 cm) in core OLTBC12 when the total production capacity based on $\mathrm{Hg}$ cell technology was the same. However, no further improvement was observed after 1999, when one (less important) mercury-based production line was decommissioned. This may be the combined result of continuous emissions from the existing Hg-based production and from the decontamination process in the factory which started in 2004 (MEWM 2006), which could result in a transfer of some additional $\mathrm{Hg}$ into the industrial canal network.

\subsection{Fate and risks of contaminated sediments}

The severe Hg pollution of the Babeni Reservoir sediments revealed in this study requires further geochemical and ecotoxicological investigations. The central problem from the aspect of risk assessment is the methylation potential of these sediments and the $\mathrm{Hg}$ availability to transfer along the food web. The presence of dark laminae may suggest that suboxic conditions, favourable for $\mathrm{Hg}$ methylation, develop periodically in the top sediment layer. Although the most contaminated sediments are now 20 years old and buried, they can be potentially reworked or resuspended by dredging or flushing. This suggests that dredging or flushing should absolutely be avoided in the Babeni Reservoir. 


\section{Conclusions}

More than 20 years of pollution chronology could be derived from one sediment core. $\mathrm{Hg}$ concentration profiles from two shorter cores confirmed reproducibility of the record in the younger sediments. Excellent temporal resolution of the record is due to a high average sedimentation rate $(5.9 \mathrm{~cm} /$ year $)$ and the absence of major sediment reworking by bioturbation. This high sedimentation rate obtained from ${ }^{137} \mathrm{Cs}$ marker was in good agreement with value calculated from sediment thickness derived from bathymetric measurement. $\mathrm{Hg}$ concentration profile reveals a huge contamination event(s) in the late 1980s and a decreasing trend since then. Hg concentrations showed large fluctuations, which can be related to both past $\mathrm{Hg}$ releases from a chlor-alkali plant and sedimentary events such as floods. Whilst in the past the direct contamination from a point source was the dominating factor of $\mathrm{Hg}$ accumulation in sediments with low concentrations in flood-generated coarser sediments, recent sediments formed during flood events are $\mathrm{Hg}$-enriched, pointing to the watershed contamination as a source of pollution of growing importance to the Babeni Reservoir. The chlor-alkali plant did not give detailed information about its $\mathrm{Hg}$ emissions, and thus, the historic and recent releases of $\mathrm{Hg}$ could not quantitatively be related to the $\mathrm{Hg}$ profile in the Babeni core. A general trend suggests improvement in emission control from the late $1980 \mathrm{~s}$ to late 1990s. However, even if the point source (the chloralkali plant) seems to be less important at present, some releases via the plant channel system still exist and need to be reduced.

$\mathrm{Hg}$ contamination of surface sediments in Babeni Reservoir is still too high with respect to the sediment quality guidelines and is one order of magnitude higher than the local background concentrations measured in the sediments from the upstream Valcea Reservoir.

Although moderately contaminated in the past with several heavy metals, Babeni surface sediments are no longer contaminated above the local background.

\section{Recommendations and perspectives}

More detailed investigation of $\mathrm{Hg}$ contamination in surface sediments should be carried out to confirm the origin of the current sources. The fate of $\mathrm{Hg}$ in the reservoirs downstream from Babeni needs to be investigated. The fraction of this metal associated with colloids and/or in dissolved phase is not known, but may be substantial and even more bioavailable. Our initial measurements indicate the presence of $\mathrm{MMHg}$ in pore water, but further studies are necessary to evaluate fluxes of $\mathrm{MMHg}$ at the sediment water interface. Samples of fish and hair from various groups in the local population were recently collected to evaluate a potential hazard of $\mathrm{Hg}$ contamination to human health in the $\mathrm{Rm}$ Valcea region.

Acknowledgement This work was financed by the Swiss National Science Foundation, the Swiss Agency for Development and Cooperation and the Romanian Ministry for Education and Research within the framework of the Swiss-Romanian cooperation programme on 'Environmental Science and Technology in Romania-ESTROM'. The reported study was performed in the project ORSED, focusing on environmental sediment contamination in the Olt River reservoirs in Romania. Presented results were obtained by a team of researchers from four Institutions: University of Bucharest, Geoecomar (Bucharest), University of Cluj and University of Geneva. Help in the fieldwork of the National Administration 'ApeleRomâne'-Olt is gratefully acknowledged. Special thanks to our colleagues, which helped in the fieldwork: Christophe Marcic, Benoit Ferrari, Radu Michaiescu and Christine Piccard.

\section{References}

Albrecht A, Reiser R, Luck A, Stoll JA, Giger W (1998) Radiocesium dating of sediments from lakes and reservoirs of different hydrological regimes. Environ Sci Technol 32(13):1882-1887

Arnason JG, Fletcher BA (2003) A 40+ year record of Cd, $\mathrm{Hg}, \mathrm{Pb}$, and $U$ deposition in sediments of Patroon Reservoir, Albany County, NY, USA. Environ Pollut 123:383-391

Audry S, Schäfer J, Blanc G, Jouanneau JM (2004) Fifty-year sedimentary record of heavy metal pollution $(\mathrm{Cd}, \mathrm{Zn}, \mathrm{Cu}, \mathrm{Pb})$ in the Lot River reservoirs (France). Environ Pollut 132:413-426

Boening DW (2000) Ecological effects, transport, and fate of mercury: a general review. Chemosphere 40:1335-1351

Castelle S, Schäfer J, Blanc G, Audry S, Etcheber H, Lissalde JP (2007) 50-year record and solid state speciation of $\mathrm{Hg}$ in natural and contaminated reservoir sediment. Appl Geochem 22:13591370

Clarkson TW (1997) The toxicology of Hg. Crit Rev Clin Lab Sci 34 (3):369-403

Dean WE (1974) Determination of carbonate and organic matter in calcareous sediments and sedimentary rocks by loss on ignition: comparison with other methods. J Sediment Petrol 44:242-248

Dominik J, Burrus D, Vernet JP (1987) Transport of the environmental radionuclides in an alpine watershed. Earth Planet Sci Let $84: 165-180$

Dominik J, Loizeau JL, Favarger PY, Vernet JP, Thomas RL (1991) History of mercury contamination reconstructed from highresolution radioisotopic dating of sediment cores in Lake Geneva. In: Vernet J-P (ed) Heavy metals in the environment. Elsevier, Amsterdam, pp 273-294

Dominik J, Loizeau JL, Span D (1992) Radioisotopic evidence of perturbations of recent sedimentary record in lakes: a word of caution for climate changes. Clim Dynam 6:145-152

Eurochlor (2007) The European chlor-alkali industry Progress report 2007. 11 pp. http://www.eurochlor.org/upload/documents/docu ment284.pdf

Förstner U (2004) Sediment dynamics and pollutant mobility in rivers: an interdisciplinary approach. Lake Reservoir Manage 9:25-40

Förstner U, Wittmann GTW (1979) Metal pollution in the aquatic environment. Springer, Berlin, pp 486 
Gray JE, Fey DL, Holmes CW, Lasorsa BK (2005) Historical deposition and fluxes of $\mathrm{Hg}$ in Narraguinnep Reservoir, southwestern Colorado, USA. Appl Geochem 20:207-220

Hylander LD, Goodsite ME (2006) Environmental costs of mercury pollution. Sci Total Environ 638:352-370

Kamman NC, Chalmers A, Clair TA, Major A, Moore RB, Norton SA, Shanley JB (2005) Factors influencing mercury in freshwater surface sediments of northeastern North America. Ecotoxicology $14: 101-111$

Lamborg CH, Fitzgerald WF, Damman AWH, Benoit JM, Balcom PH, Engstrom DR (2002) Modern and historic atmospheric mercury fluxes in both hemispheres: global and regional mercury cycling implications. Glob Biogeochem Cycles 16:1104

Linnik PM, Zubenko IB (2000) Role of bottom sediments in the secondary pollution of aquatic environments by heavy metal compounds. Lake Reservoir Manage 5:11-21

Loizeau JL, Arbouillle D, Santiago S, Vernet JP (1994) Evaluation of a wide range laser diffraction grain size analyser for use with sediments. Sedimentology 41:353-361

Loizeau JL, Pardos M, Monna F, Peytremann C, Haller L, Dominik J (2004) The impact of a sewage treatment plant's effluent on sediment quality in a small bay in Lake Geneva (SwitzerlandFrance). Part 2: temporal evolution of heavy metals. Lake Reservoir Manage 9:53-63

MacDonald DD, Ingersoll CG, Berger TA (2000) Development and evaluation of consensus-based sediment quality guidelines for freshwater ecosystems. Arch Environ Contam Toxicol 39:20-31

MEWM (2006) Letter related to the national report of Romania regarding the information on mercury. Ministry of Environment and Water Management, http://www.chem.unep.ch/MERCURY/ Trade $\% 20$ information/Romania-Mercury $\% 20$ situation $\% 20$ on $\%$ 20a\%20national\%20level_mai_2006.pdf

Osol, Office Fédéral de la Protection de l'Environnement (1998) Ordonnance du 1er juillet 1998 sur les atteintes portées aux sols. No. 814.12

Skyllberg U, Drott A, Lambertsson L, Björn E, Karlsson T, Johnson T, Heinemo SA, Holmström H (2007) Net methylmercury produc- tion as a basis for improved risk assessment of mercurycontaminated sediments. Ambio 36:437-442

Sugai SF, Alperin MJ, Reeburgh WS (1994) Episodic deposition and ${ }^{137} \mathrm{Cs}$ immobility in Skan Bay sediments: a ten-year ${ }^{210} \mathrm{~Pb}$ and ${ }^{137} \mathrm{Cs}$ time series. Mar Chem 116:351-372

Tomiyasu T, Matsuyuma A, Eguchi T, Fuchigame Y, Oki K, Horvat M, Rajar R, Akagi H (2006) Spatial variations of mercury in sediment of Minamata Bay, Japan. Sci Total Environ 368:283-290

Ullrich SM, Tanton TW, Abdrashitova SA (2001) Mercury in the aquatic environment: a review of factors affecting methylation. Critical Rev Environ Sci Technol 31:241-293

Ullrich SM, Ilyushchenko MA, Uskov GA, Kamberov IM, Tanton TW (2007) Mercury contamination in the vicinity of a derelict chlor-alkali plant. Part 1: sediment and water contamination of Lake Balkyldak and the Tiver Irtysh. Sci Total Environ 381(13):290-306

UNEP chemicals (2002) Global Mercury Assessment. Report no 54790-01. Geneva, Switzerland. http://www.chem.unep.ch/mer cury/Report/Final\%20Assessment\%20report.htm

Ungureanu GV (2007) Environmental Assessment of the Olt River Reservoirs in the Region of Rm. Vâlcea: Focus on Suspended Matter and Sediments, Final ESTROM meeting, Iasi

USEPA (US Environmental Protection Agency) (1997) Mercury Study Report to Congress, Vol. 3, EPA-452/R-97-003. Office or Air Quality Planning and Standards, Office of Research and Development, Washington, DC. (Chapter 4)

Vernet JP, Viel M (1984) Métaux lourds dans les sédiments lacustres. Annual report. Synthesis 1957-82. Commission Internationale pour la Protection des Eaux du Léman contre la Pollution, Lausanne

Vink R, Behrendt H (2001) Part B: present and future quality of sediments in the Rhine catchment area-heavy metals. In: Candrass J, Salomons W (eds) Dredged material $\mathrm{n}$ the port of Rotterdam-interface between Rhine catchment area and North Sea. GKSS, Geesthacht, Germany

Wihlborg P, Danielsson A (2006) Half a century contamination in lake Vänern (Sweden). Water Air Soil Pollut 170:285-300 